\title{
HISTOPATHOLOGICAL CHANGES OF KIDNEY OF BROILER CHICKEN EXPOSED TO CHRONIC HEAT STRESS
}

\author{
Irene Teh Kai Xin 1), Hani Plumeriastuti 2), Chairul Anwar 2), Kadek Rahmawati 2), \\ Suzanita Utama 2), Djoko Legowo ${ }^{2)}$
}

\author{
1) Mahasiswa, 2) Dosen \\ Fakultas Kedokteran Hewan Universitas Airlangga \\ Kampus C UNAIR, Jl. Mulyorejo-Surabaya 60115 \\ Telp. 031-5992785, Fax. 031-5993015 \\ Email: jbmvunair@gmail.com
}

\begin{abstract}
The aim of this research was to know histopathological changes of kidney of broiler chicken exposed to chronic heat stress. Twenty broilers were divided randomly into 2 groups, 10 broilers each are being exposed to chronic heat stress for 21 days. The first 21 days were the adaptation period in a chamber with temperature $24-28^{\circ} \mathrm{C}$ and humidity $40-55 \%$. After 21 days, continue with exposure to heat stress in a chamber with temperature $36-40^{\circ} \mathrm{C}$ and humidity $50-65 \%$ in 8 hours per day. After exposed to chronic heat stress, kidney tissues were processed, and kidney tissue histopathological changes were evaluated by using the Klopfleisch modified scoring method. The data was analyzed by Mann - Whitney Test. The result of this research showed that chronic heat stress exposure causing the presence of degeneration of tubular epithelial cell, necrosis of tubular epithelial cell, necrosis of glomerular and interstitial infiltration. From the analysis data the overviewof multiparametric showed that when control group compared with the treatment group showed significantly difference $(\mathrm{p}<0.05)$.
\end{abstract}

Key words: chronic, heat stress, kidney, broiler

\section{BACKGROUND}

Heat stress is the result of a negative balance between the net amount of energy flowing from the animal's body to its surrounding environment and the amount of heat energy produced by the animal itself. This imbalance may be caused by variations of a combination of environmental factors for example sunlight, thermal irradiation, air temperature, humidity and characteristics of the animal like species, metabolism rate and thermoregulatory mechanisms.

Environmental stressors, such as heat stress, are particularly detrimental to animal agriculture. Thus, the negative impacts of environmental stressors issue have become a sign of awareness and matter to be concern towards the public (Lara and Rostagno, 2013).

Particularly, poultry are sensitive to temperature - associated environmental challenges, especially heat stress (Deeb, et al., 2002). According to Charles (2002), growing broilers perform better in relatively extended range of optimal temperature of around $18^{\circ} \mathrm{C}$ to $22^{\circ} \mathrm{C}$, with temperatures above this range reducing performance and ultimately resulting in heat related stress (Kilic and Simsek, 2013). Poultry with one special characteristic different with others mammals are they do not have sweet glands and almost all part of its body is coverage with feather. Thus, with such biological conditions that have causes the poultry to have 
difficulty to let out the heat in their body to the environment during the hot environment (Tamzil, M.H., 2014).

Heat stress can enforce many body systems to the limits of regulatory ability. Thus the stress response includes the complex responses to maintain the constant condition of the broiler (Narongsak, 2004). According to Ewing et al., (1999), primer examples of such response were increased of heart rate and the blood flow to muscle, brain and heart. This also might cause congestion in kidney.

Kidneys play an important role in body homeostasis by adapting the renal excretion of fluid and electrolytes to body needs to under control of a systemic neurohumoral adjustment (Volker et al., 2006). However, only few studies on the pathological changes in kidney under the intense work for the period of heat stress (Huang et al., 2017).

\section{RESEARCH MATERIALS AND METHOD}

\section{Material and Equipments}

This experimental animals used in this research were 20 broiler chicken day old chicks (DOC). The chickens were of Cobb Wonchick strain and obtained from PT. Wonokoyo Jaya Corporindo.

The main equipment that used in this research were two-separated chamber, which is chamber $\mathrm{A}$, and chamber B. Chamber A was equipped with an air conditioner (AC) and 2 exhaust fan. Chamber $B$ as the treatment group of chronic heat stress were equipped with 3 light bulbs (Philips 160 Watt) high-pressure mercury lamps, all arranged in a line. In chamber $A$ there was a digital temperature and humidity meter. The same went for chamber B, except it was further equipped with an alcoholbased room thermometer. The chickens's chambers were built within by dividing the room into two (similar size) with wooden boards, also each of them was enriched with chicken drinkers and feeders.

The chamber indicated for all growth phases of the chicken were 2 spaces, chamber $\mathrm{A}$ and chamber $\mathrm{B}$ (each measuring $1.5 \mathrm{~m} \times 1.5 \mathrm{~m}$ ), built inside a room and separated from each other with wooden boards and later on a thick screen. The housing system used throughout the research was deep litter.

\section{Treatments}

Preparation of brooding house started a week before the DOC was being placed in the chamber, the surrounding of the room and also the equipment has to be disinfectant. To rear the broilers are included commercial broiler chicken feed for starter and grower CP511 tap water as drinking water, multivitamin, ND +IB and gumboro vaccines, disinfectant, and rice hulf as the litter for the broiler.

The 1-day-old chickens were reared at the thermo neutral zone until the age of 21 days old. A total of 20 DOC were then reared inside the chamber until the age of 21 days in accordance with standards breeding requirement. The chicks were fed starter diet CP 511 production from PT. Charoen Pokhpand, and provided with tap water ad libitum as drinking water. $\mathrm{ND}+\mathrm{IB}$ vaccine was administered at day 6, while Gumboro vaccine was administered at day 14 .

Upon reaching day 22, the broiler chickens, as experimental animals, were exposed to either chronic heat stress or thermoneutral zone. The broiler chickens were being fed with on finisher diet CP 511 production from PT. Charoen Pokhpand, with tap water ad libitum as drinking water. There were a total of 20 broiler chicken used in this research which had been divided into 2 
treatment groups with each group have 10 replicates. One of the groups of chicken broilers was exposed to chronic heat stress.

T0 (Control):

Broilers chicken reared under $24-28^{\circ} \mathrm{C}$ and $\mathrm{RH} 40-55 \%$

T1 (Treatment):

Broilers chicken reared under $36-40^{\circ} \mathrm{C}$ and $\mathrm{RH} 50-65 \%$ for 8 hours/d, then at $24-28^{\circ} \mathrm{C}$ and $\mathrm{RH} 40-55 \%$ for the rest of the day.

Temperature and relative humidity $(\mathrm{RH})$ that were used in this research are different temperature and $\mathrm{RH}$ in two chambers. Chamber A with the temperature is $24-28^{\circ} \mathrm{C}$ was generated by $A C$ and exhaust fans while chamber B's temperature was generated by the three mercury lamps switched on at 8 o' clock in the morning continuously 8 hours/d with the temperature of $36-40^{\circ} \mathrm{C}$ then at $24-28^{\circ} \mathrm{C}$ for the rest of the day. $\mathrm{RH}$ is defined as the ratio current amount of air moisture-holding capacity of the air at given temperature. The $\mathrm{RH}$ of chamber $\mathrm{A}$ is at $40-55 \%$ while the $\mathrm{RH}$ of chamber B is at $50-65 \%$. The T0 group's temperature and $\mathrm{RH}$ were modified from the study Al-Fataftah and Abu-Dieyeh (2007). On the other hand, the T1 group's temperature range was determined by combining the ones used in researches by Huang et al. (2017). Both the temperature and $\mathrm{RH}$ were regulated manually in accordance with a digital temperatureand-humidity meter coupled with an alcohol-based room thermometer. These treatments proceeded until the broiler chickens reached day 42 .

\section{Experimental Design}

The research uses the true experimental design, specifically the post-test only control group design. In this research, the source of variability comes from the treatment, in additional to individual variation (Error). This research was done with a total of 20 broiler chicken were divided into 2 groups which consist of 10 replicates for each group.

\section{Data Analysis}

Scored data of each group will be analysed statistically using MannWhitney with $p<0,05$. Statistical analysis for this experiment is using SPSS 23.0 for Windows software using descriptive analytic to compare the treatment effect of each group.

\section{RESERARCH RESULT}

This research was examined by histopathological changes of kidney of broiler chicken which exposed to chronic heat stress. Histopathological changes in kidney observed are degeneration of tubular epithelial cell, necrosis of tubular epithelial cell, necrosis of glomerulus and interstitial infiltration. 
Irene. dkk. Histopathological Changes of Kidney of Broiler Chicken Exposed to Chronic Heat

Table 4.1 Comparison of histopathological changes of kidney of broiler chicken exposed to chronic heat stress between control group (T0) and treatment group (T1).

\begin{tabular}{cc}
\hline Treatment & (Scored, Mean \pm Standard Deviation) \\
\hline T0 & $7.50 \pm 2.42$ \\
\hline T1 & $10.30 \pm 3.06$ \\
\hline
\end{tabular}

Different superscript in the same column indicate significant difference $(\mathrm{P}<0.05)$; $\mathrm{T} 0=$ control group $\mathrm{T} 1=$ Treatment group; Replicates $=10$
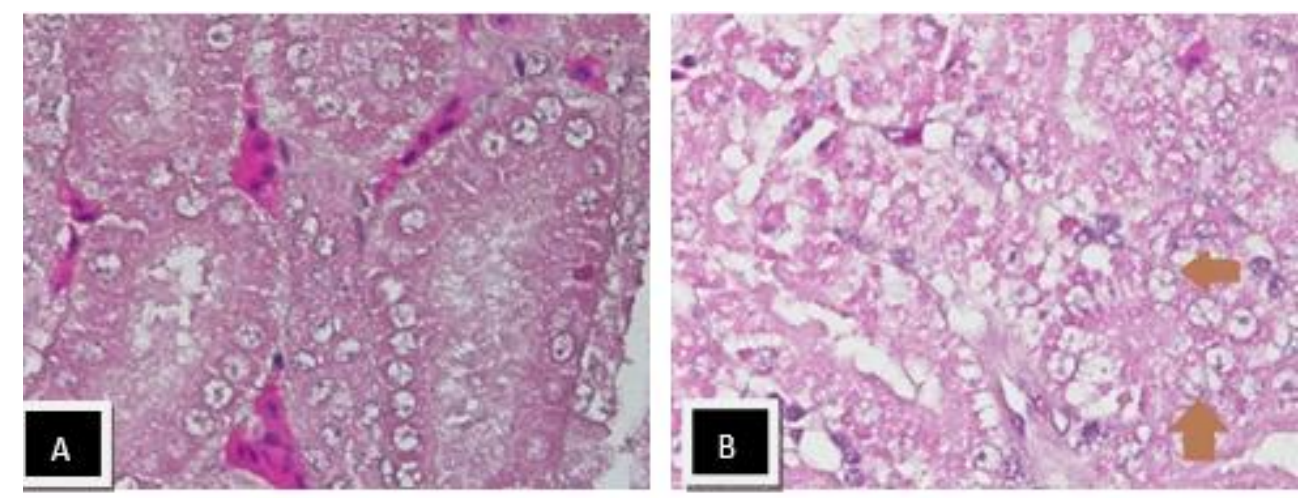

Figure 4.1 Histopathological changes of kidney on broiler chicken. (A) In control group (T0) the tubular epithelial cell of the kidney seen normal. (B) In treatment group (T1) Degeneration epithelial tubule cells can be seen pointed by the brown arrow and with the presence of cytoplasmic vacuolation (Stain: HE; Magnification: 1000x).

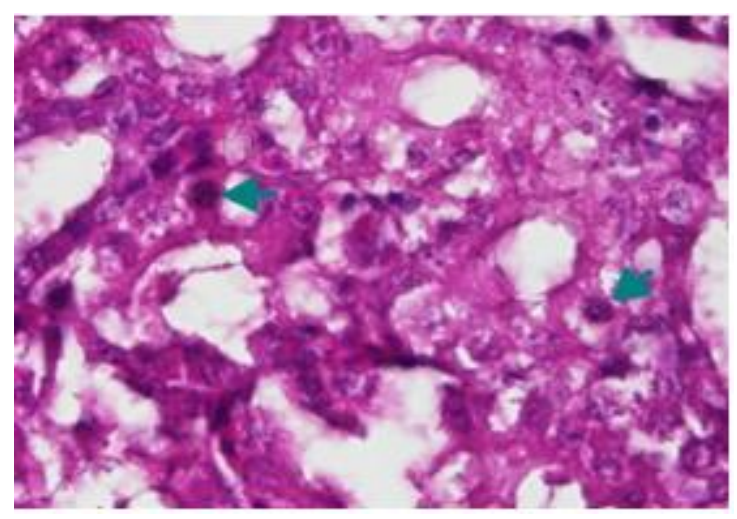

Figure 4.2 Histopathological changes of kidney on broiler in treatment group (T1). Piknotis cell of kidney can be seen pointed by the green arrow. (Stain: HE; Magnification: 1000x). 

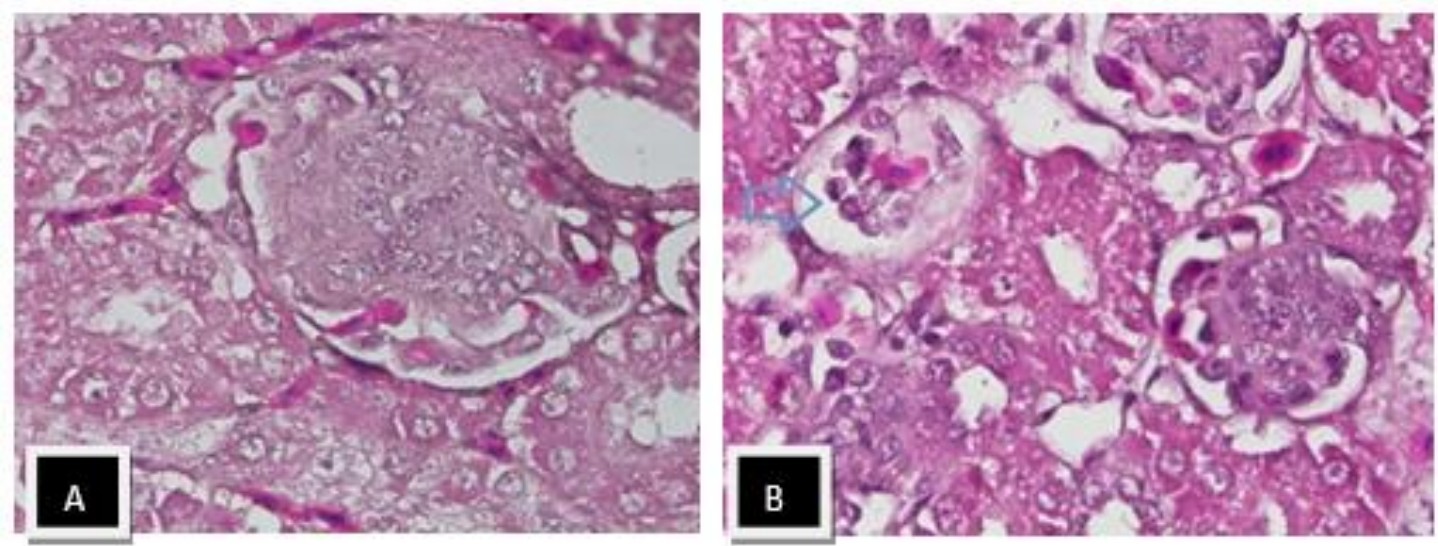

Figure 4.3 Histopathological changes of kidney on broiler (A) in control group (T0). Glomerulus kidney broiler chicken can be seen normal. (B) Treatment group can be seen necrosis of glomerulus can be seen pointed by the blue arrow). (Stain: HE; Magnification: 1000x).
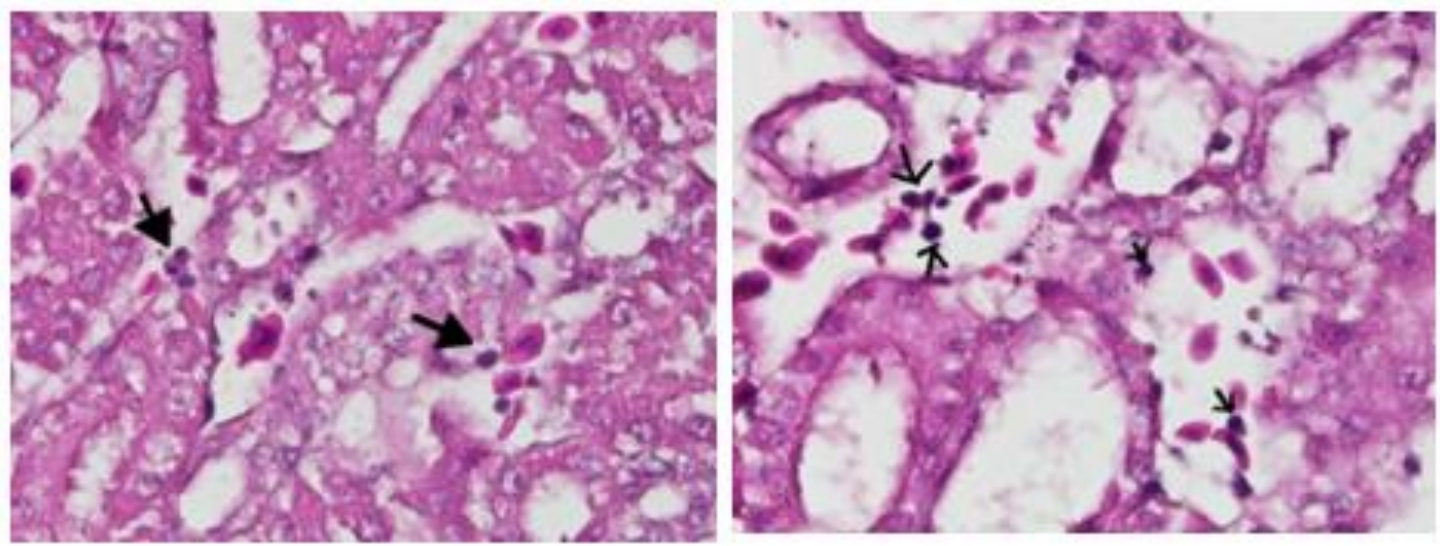

Figure 4.4 Histopathological changes of kidney on broiler in treatment group (T1). Infiltration of limfosit cell in between the interstitial pointed by the black arrow. (Stain: HE; Magnification: 1000x).

\section{DISCUSSION}

The result of statistical analysis showed that when compared with the control group (T0) was significantly difference between treatment group (T1) with the exposure of chronic heat stress. The histopathological of kidney in the treatment group showed that the presence of degeneration and necrosis of epithelial cell, necrosis glomerulus and interstitial infiltration.

Degeneration cell are the earliest reactions that can be seen before the happen of necrosis at the tissue. The best studied of degeneration cell and necrosis cell are the lack of $\mathrm{O} 2$ induced the failure of synthesis ATP that lead to failure of $\mathrm{Na}+\mathrm{K}+$ pumps and loss of cell volume control (Mc Gavin and Zachary, 2007).

Cell degeneration cell is also known as cell swelling, hydropic degeneration or vacuolar degeneration. Due to the overload of water, the size and volume of cell increases that cause a failure of cell to maintain normal homeostasis. Degeneration cell usually 
involves damage of the cellular membranes, deficiency of the cellular energy production or injury to enzymes regulating ion channels of membranes (Mc Gavin and Zachary, 2007). According to Huang et al., (2003) when heat stress occurs on animals it will eventually decreased the oxygen intake, this is because of the presence of abnormalities at the lung tissues.

Injured cells can no longer regulate water and electrolytes are no better provide to maintain the cell functions. However, it is still depending on the number of cell affected and the lost of cell function. Cell swelling can be result in necrosis or can be irreversible. Cell being injured with an irreversible restore consist of two factors, which is mitochondrial function and the cellular membrane damage. The cells necrosis is cause by the influx of $\mathrm{Ca} 2+$ that inhibits oxidative phosphorylation leading to mitochondrial damage leads to inadequate of ATP (Mc Gavin and Zachary, 2007).

Renal tubule epitheliums cell is highly vulnerable to hypoxia and cell swelling (Mc Gavin and Zachary, 2007). From the study of Cheville (1999), there is evidence of renal failure that caused by degeneration and necrosis on renal tubular. Especially, fatty degeneration could be mainly found in renal tubules epithelial cell of the broilers. From the explanation of Caspani et al., (2004) when heat stress occurs the body will response thermoregulatory efforts to reduce the heat formation and increase the heat dissipation. Due to the cells are being impaired by the production of energy and eventually have triggered the proses of degeneration and necrosis. Wideman et al., (1994) have reported that the study of broilers being exposed to $35^{\circ} \mathrm{C}$ of ambient temperature had significantly lower glomerular filtration rates (GFR), filtered loads of sodium and the rates of control birds. These changes tubular sodium reabsorption rates than of kidney function are hypothesized to minimize urinary fluid and solute loss when heat stress occurs on broilers consumes large quantities of water to supports evaporation cooling. Aengwanich et al., (2004) reported that the glomerulus was being destroyed. These changes are similar to the effects of heat stress on broilers in this study. The presences of infiltration of inflammatory cells on kidney tissue are allegedly related with the abnormality of the body response due to the activation of thermoregulatory. When chicken is suffering heat stress, their body will release various type of biochemical compounds such as glucocorticoid hormones and cytokines. As cytokine holds an important role on maintaining the homeostasis of the body due to the stress (Huang et al., 2003). When heat stress is going on, thus the synthesis of cytokine will increase, and eventually will increases the response of inflammation (Caspani et al., 2004). the heat, HSP becomes uncontrollable that causing some types of cellular proteins damages (Demacario et al., 2000) and lead to the incidence of apoptosis and necrosis will increases.

Overall of this research, proved that the previously studies have the similarities of there are presence of degeneration and necrosis epithelial cell, necrosis glomerulus and interstitial infiltration.

\section{CONCLUSIONS}

Chronic heat stress can cause histopathological changes of kidney of broiler chicken exposed to chronic heat stress by the presence of degeneration of tubular epithelial cell, necrosis of tubular epithelial cell, necrosis of glomerulus and interstitial infiltration. 


\section{REFERENCES}

Aengwanich, W. and S. Simaraks, 2004. Pathology of heart, lung, liver and kidney in broilers under chronic heat stress. Songklanakarin Journal Science Technology., 26(3):417-424.

Caspani, M.L., Savioli, M., Crotti, S., Buzzone, P., and Gattmoni, L. 2004. Heat Stress Characteristics, Pathophysiology and Avoidable Mistakes. Minerva Anastesiol, 70: 617-624.

Charles, D. R. 2002. Responses to the thermal environment. In: Charles and Walker (eds) Poultry Environment Problems, a guide to solutions. Nottingham University Press, UK; pp 1-16.

Cheville, N.F. 1999. Introduction to Veterinary Pathology, Second Edition, lowa State University Press/Ames.

Deeb, N. and A. Cahaner. 2002. Genotype - by- environment interaction with broiler genotypes differing in growth rate. 3. Growth rate and water consumption of broiler progeny from weight-selected versus nonselected parents under normal and high ambient temperatures. Poultry Science.81, 293-301.

Demaecario, E. C. and A.J.L. Macario. 2000. Stressors, Stress and Survival; overview. Frontiers in Bioscience. 5:780-786.

Huang, K. L., C. P. Wu., Y. L. Chen, B. H. Kang and Y. C. Lin. 2003. Heat Stress Attenuates Air BubbleInduced Acute Lung Injury: A Novel Mechanism of Diving
Acclimatization. Journal Applied Physiology., 94: 1485 - 1490.

Huang, S.C., Y.F. Fu1, Y. F. Lan, M.U. Rehman and Z. X. Tong. 2017. Histopathological and biochemical evaluations of the kidney in broiler chickens under acute heat stress conditions. Indian Journal of Animal Research., 588:1-3.

Kilic, I., \& Simsek, E. 2013. The Effects of Heat Stress on Egg Production and Quality of Laying Hens. Journal of Animal and Veterinary Advances, 42-47.

Lara, L.J and M.H. Rostagno. 2013. Impact of Heat Stress on Poultry Production. Animals, 3: 356-369.

McGavin, M. D and Zachary J. F. 2007. Pathologic Basis of Veterinary D isease. 4th ed. ISBN-13: 978-0323-02870-7. p. 166.

Narongsak Chaiyabutr. 2004. Physiological Reations of Poultry to Heat Stress and Methods to Reduce its Effect on Poultry Production. Thai Journal Veterinary Medicine. 34:2.

Tamzil, M.H. 2014. Stress Panas pada Unggas: Metabolisme, Akibat dan Upaya Penanggulangannya WARTAZOA 24:57-66.

Volker, V., M. Bernd, and O. Hartmut. 2006. Adenosine and kidney function. Physiology Reviews. 86: 901-940.

Wideman, R.F., Ford, B.C., May, J.D. and Lott, B.D. 1994. Acute heat climation and kidney function in broilers Poultry Science.73:75-88. 